Al-Mujtahid: Journal of Islamic Family Law Vol. 1, No. 1 (2021): 24-35

Website: http://journal.iain-manado.ac.id/index.php/almujtahid

\title{
PANDANGAN HAKIM TERHADAP KELALAIAN NAFKAH ANAK PASCA PERCERAIAN DI PENGADILAN AGAMA TONDANO
}

\section{Frangky Suleman}

Fakultas Syariah, Institut Agama Islam Negeri Manado, Indonesia

Email: frangkysuleman@iain-manado.ac.id

\begin{abstract}
ABSTRAK
Pandangan Hakim Pengadilan Agama Terhadap Kelalaian Nafkah Anak Pasca Perceraian. Pandangan merupakan kata serap dari kata pandang yang berarti mengamati, menganalisa, berpendapat, serta memperhatikan sesuatau yang dianggap perlu. Dalam hal ini hakim pengadilan agama mempunyai wewenang penuh untuk mengambil sebuah keputusan dalam berperkara di pengadilan khususnya pengadilan agama. Hasil penelitian menunjukan bahwa pentingnya tuntutan nafkah anak di masukan ke dalam isi surat gugatan bukan hanya ingin berpisah, atau pun tentang harta bersama melainkan juga tentang keberlangsungan hidup anak mulai dari, kenyamanan, pertumbuhan serta perkembangan anak tersebut. Karena jikalau tidak di masukan dalam isi surat gugatan maka tidak ada kekuatan hukum sama sekali apa bila mengadu ke Pengadilan.
\end{abstract}

Kata kunci: Hakim; Nafkah Anak; Perceraian. 


\section{PENDAHULUAN}

Perceraian merupakan suatu perbuatan yang dihalalkan oleh Allah Swt namun juga hal yang paling di benci oleh-Nya. Namun dilihat lagi apabila perkawinan tersebut lebih banyak mudharat dari pada manfaatnya, maka perceraian itu di bolehkan. Perceraian adalah sebagai upaya atau jalan terakhir setelah segala upaya untuk mendamaikan suami-istri telah ditempuh namun tidak berhasil karena pada prinsipnya tujuan perkawinan sesuai dengan Kompilasi Hukum Islam, ialah untuk mewujudkan keluarga atau rumah tangga yang sakinah (kebahagiaan), mawaddah (kasih sayang) dan rahmah (Wasman \& Nuroniyah, 2011) namun jika suami-istri harus mempertahankan perkawinannya dalam keadaan tidak bahagia, dan sejahtera ditakutkan akan menimbulkan masalah-masalah lebih lanjut. Sebagaimana dalam Undang-Undang Nomor 16 tahun 2019 tentang perkawinan terhadap perubahan Undang-undang Nomor 1 tahun 1974 Pasal 39 ayat (1) dan (2) yaitu, perceraian hanya dapat dilakukan didepan sidang Pengadilan setelah Pengadilan yang bersangkutan berusaha dan tidak berhasil mendamaikan kedua belah pihak. Untuk melakukan perceraian harus ada cukup alasan, bahwa antara suami-istri itu tidak akan dapat hidup rukun sebagai suami-istri (Tim Redaksi BIP, 2017).

Perceraian bukanlah solusi terakhir untuk menyelesaikan konflik keluarga, pasca perceraian banyak hal yang juga harus di pertanggungjawabkan pada relasi suami-istri, terutama yang memiliki keturunan, karena masalah yang sering muncul pasca perceraian adalah persoalan nafkah istri dan nafkah anak, harta bersama dan pengasuhan anak. Suatu perkawinan yang sudah putus karena perceraian tidaklah mengakibatkan hubungan antara orang tua (suami dan istri yang telah bercerai) dan anak-anak yang lahir dari perkawinan tersebut menjadi putus. Sebab dengan tegas telah diatur bahwa suami dan istri yang telah bercerai tetap mempunyai kewajiban yaitu untuk memelihara dan mendidik anak-anaknya, termasuk dalam hal pembiayaan yang timbul dari pemeliharaan dan pendidikan anak tersebut. hanya hak asuh yang pindah ke salah satu pihak yaitu beralih ke ayah atau ke ibunya (Rodliyah, 2014).

Kelahiran anak sebagai peristiwa hukum yang terjadi karena hubungan suamiistri, membawa konsekuensi berupa hak dan kewajiban secara timbal balik antara orang tua dan anak. Anak dalam keluarga adalah amanah Allah yang perlu dipelihara dengan sebaik-baiknya. Anak mempunyai hak-hak tertentu, baik hak yang menjadi kebutuhan material anak, seperti; sandang, pangan dan papan, maupun hak immaterial anak, seperti; hak beribadah, hak mendapatkan perhatian dan kasih sayang, sekaligus hak berinteraksi sosial. Salah satu hak anak yang sangat penting untuk dipenuhi oleh orang tua adalah hak nafkah (alimentasi). Pemenuhan hak nafkah 
anak, merupakan bentuk implementasi dari tujuan pernikahan, sebagai media ampuh yang berperan secara aktif ofensif untuk melindungi keturunan.

Nafkah menurut kesepakatan ulama adalah belanja untuk keperluan makanan yang mencangkup sembilan bahan pokok disingkat sembako, pakaian dan perumahan atau dalam bahasa sehari-hari disebut sandang, pangan dan papan (Rozi, 2019). Selain itu M. Yahya Harahap menyebutkan bahwa yang dimaksud dengan pemeliharaan anak adalah: 1). Tanggung jawab orang tua untuk mengawasi, memberikan pelayanan yang semestinya serta mencukupi kebutuhan hidup anak. 2). Pemeliharaan yang berupa pengawasan, pelayanan serta pencukupan nafkah anak tersebut adalah bersifat continue (terus menerus) sampai anak itu dewasa (Suyanto, 2000)

Dalam Kitab Undang-Undang Hukum Perdata (BW) Pasal 330 ayat 1 menyatakan bahwa anak adalah mereka yang belum mencapai umur 21 tahun dan yang sebelumnya tidak pernah kawin. Sedangkan dalam Undang-undang Nomor 39 Tahun 1999 tentang HAM Pasal 1 angka 5 menyebutkan bahwa anak adalah setiap manusia yang berusia dibawah 18 tahun dan belum menikah, termasuk anak yang masih dalam kandungan apabila hal tersebut adalah demi kepentingannya. Sedangkan menurut Undang-undang Nomor 23 Tahun 2002 tentang Perlindungan Anak Pasal 1 angka 1 menyebutkan bahwa anak adalah seseorang yang belum berusia 18 tahun, termasuk anak yang masih dalam kandungan. Untuk menjamin kesejahteraan dan ketentraman anak, di Indonesia diberlakukan Undang-Undang yang mengatur secara rinci masalah hadanah dan biaya pemeliharaan anak akibat perceraian untuk memberikan perlindungan bagi masa depan anak secara hukum baik dalam hukum Islam maupun dalam hukum Positif, kewajiban untuk menafkahi keluarga (khususnya anak) merupakan kewajiban primer seorang suami menurut kemampuannya (Rijal, 2017).

Selaras dengan Undang-undang Nomor 1 tahun 1974 tentang perkawinan juga mengatur secara garis besar, tentang akibat hukum sebab berakhirnya pernikahan karena perceraian, dengan bertitik berat pada terjaminnya kesejahteraan serta kepentingan hidup anak-anak, kemudian tentang pengurusan, pengasuhan dan pemeliharaan anak diatur dalam Pasal 41 yang memuat ketentuan sebagai berikut; 1 . Baik ibu ataupun bapak tetap berkewajiaban memelihara dan mendidik anakanaknya, semata-mata berdasarkan kepentingan anak. Bilamana ada perselisihan mengenai penguasaan anak-anak, pengadilan berwenang memberi keputusannya. 2 . Bapak yang bertanggung jawab atas semua biaya pemeliharaan dan pendidikan yang diperlukan anak itu. Bilamana bapak dalam kenyataan tidak dapat memenuhi kewajiban tersebut, pengadilan dapat menentukan bahwa ibu ikut memikul biaya tersebut 3. Pengadilan dapat mewajibkan kepada bekas suami untuk memberikan 
biaya penghidupan dan/atau menentukan suatu kewajiban bagi bekas istri (Tim Redaksi BIP, 2017).

Kemudian dalam Kompilasi Hukum Islam Pasal 156 bagian (d) mengenai akibat dari putusnya pernikahan, yaitu semua biaya hadanah dan nafkah anak menjadi tanggung jawab ayah menurut kemampuannya, sekurang-kurangnya sampai anak tersebut dewasa dapat mengurus diri sendiri. Kemudian juga terdapat dalam hadits Dari Aisyah R.A berkata: Hindun binti Utbah istri Abu Sufyan datang kepada Nabi Muhammad SAW, lalu mengatakan: Hai Rasulullah, bahwa Abu Sufyan itu orang kikir. Dia tidak memberikan kepada saya yang mencukupi bagi saya dan anak saya, selain yang saya ambil dari padanya secara sembunyi-sembunyi, dan ia tidak mengetahuinya. Maka adakah dosa bagi saya pada yang demikian itu?\| maka nabi SAW bersabda: - ambillah yang cukup untuk nafkahmu dan nafkah anak-anakmu dengan cara yang baik (Al Bukhari, tt).

Di lihat dari hukum-hukum yang diatur baik dalam hukum Islam maupun hukum Positif, bahwa setiap orang tua yang telah bercerai agar tidak melalalaikan nafkah anak. Terkhususnya bagi orang tua laki-laki karena kedudukan ibu dalam memberi nafkah kepada anak hanya apabila ayah tidak mampu menafkahi, kemudian pengadilan yang bersangkutan memutuskan bahwa ibu ikut memikul biaya tersebut. sebagaimana yang terdapat dalam Undang-undang Nomor 16 tahun 2019 tentang perkawinan terhadap perubahan Undang-undang Nomor 1 Tahun 1974. Karena pada dasarnya ayahlah yang bertanggung jawab atas segala biaya pemeliharaan anak tersebut.

Persoalan nafkah anak pasca perceraian ini sering kali menjadi problem karena terkadang hak-hak anak ada yang dikesampingkan dan kurang terurus dengan serius, walaupun pada hakikatnya segala hukum telah mengatur tentang hal tersebut namun tetap saja orang tua masih melalaikan tanggung jawabnya, terutama yang berkaitan dengan hak-hak pokok anak yaitu biaya pemeliharaan, pendidikan, tempat tinggal dan fasilitas-fasilitas penunjang lainnya. Meskipun orang tua sudah tidak bersatu lagi dalam keluarga, persoalan pemenuhan nafkah anak tetap menjadi tanggung jawab orang tua dan hal ini tidak boleh dialihkan kepada orang lain, baik orang tua, kerabat dan lainnya (Susantin, 2014)

Adanya kelalaian dalam memberikan nafkah merupakan permasalahan yang sering terjadi dikalangan masyarakat. Terjadinya hal tersebut disebabkan kurangnya pemahaman masyarakat terhadap ketentuan-ketentuan agama dan peraturan negara serta kurangnya kesadaran masyarakat tentang bagaimana pentingnya melaksanakan kewajiban pemberian nafkah atau pihak yang berhak memperoleh nafkah juga kurang 
pengetahuannya tentang cara menuntut hak-haknya. Akibatnya tidak sedikit anak yang nafkahnya terlalaikan (Rijal, 2017).

Sebagaimana kasus yang terjadi di daerah pedesaan penulis (Desa Molompar Kecamatan Belang), suami-istri yang telah bercerai tepatnya pada tahun 2015 di Pengadilan Agama Tondano. Mereka memiliki dua orang anak, setelah perceraian, ayah dari anak-anak tersebut tidak pernah memberikan nafkah, baik untuk biaya pemeliharaan maupun biaya pendidikan. Padahal ayah kedua anak tersebut mampu secara fisik maupun materi. Dari pihak mantan istri juga tidak menuntut nafkah anak pada saat menggugat suaminya, karena alasan mantan istri tidak tau mengenai pengurusan nafkah anak di Pengadilan Agama serta pada saat itu yang ada dalam pikiran hanya perceraian saja, sehingga hal ini menjadi salah satu penyebab nafkah anak terlalaikan, namun menurut penulis seharusnya seorang ayah mempunyai rasa tanggung jawab, dan hati nurani, karena dengan perbutannya yang melalaikan nafkah, memaksa dan membiarkan kepada mantan istrinya atau ibu anak-anak tersebut bekerja lebih keras untuk memenuhi biaya pemeliharaan dan pendidikan anakanaknya. Padahal yang seharusnya dalam aturan hukum yang bertanggung jawab atas biaya pemeliharaan dan pendidikan adalah ayah dan menafkahi anakanaknya sampai anak itu dewasa. Sebagaimana yang diatur dalam Undang-undang Nomor 16 Tahun 2019 Pasal 41 dan Kompilasi Hukum Islam (KHI) Pasal 156 bagian (d) mengenai akibat dari putusnya Perkawinan. Hal ini jelas bertolak belakang dengan ketentuan syariah maupun peraturan negara

\section{METODE PENELITIAN}

penelitian ini adalah penelitian hukum,dalam perkembangan metode penelitian hukum penelitian hukum normatif dan penelitian hukum penelitian hukum empiris harus di combaign atau digunakan keduanya karena dengan menggabungkan kedua penelitian tersebut akan memberikan hasil penelitian yang komprehensif (Amiruddin, 2004).

\section{HASIL DAN PEMBAHASAN}

\section{Faktor Penyebab Terjadinya Kelalaian Nafkah Anak Pasca Perceraian}

Nafkah adalah biaya atau pengeluaran seorang suami yang wajib diberikan kepada istri dan anak-anak, dalam memenuhi kehidupan sehari-hari baik berupa sandang, pangan dan papan. Masalah nafkah adalah masalah yang sangat pokok dalam kehidupan ini. Tanpa adanya nafkah juga sangat berpengaruh dalam kehidupan rumah tangga. Dalam membangun keluarga tidak akan tercapai keluarga yang 
bahagia tanpa tercukupinya nafkah. Dalam hal ini merupakan kewajiban suami sebagai kepala keluarga, meskipun telah terputus perkawinannya.

Hal nya yang dibutuhkan untuk memenuhi kebutuhan anak kecil, seperti makan, minum, tempat tidur, obat-obatan dan kebutuhan dasar lain yang memang dibutuhkan anak-anak. Dengan adanya nafkah yang cukup, maka akan tercipta suatu kebahagiaan, tetapi sebaliknya kekurangan nafkah akan menyebabkan terjadinya bermacammacam kerusakan sehingga memunculkan dampak dari adanya kejahatan. Hal itu juga akan mempengaruhi pola berfikir seorang anak, selain juga memunculkan dampak, kelalaian nafkah anak juga di sebabkan oleh 3 faktor yaitu:

a. Tidak Dimasukan Tuntutan Nafkah Anak dalam Isi Surat Gugatan

Perceraian merupakan sesuatu perbuatan atau keputusan yang diambil di karenakan sudah tidak ada lagi kecocokan antara suami istri. Kebanyakan istri menggugat cerai suaminya karna suami sudah tidak menafkahi, sering terjadi kekerasan dalam rumah tangga, suami sudah kawin kembali tanpa izin istri dan masih banyak hal lainya. Semua tindakan yang diambil akan berunjung ke pemberian nafkah pasca perceraian. Seperti kebanyakan yang terjadi istri mengajukan perkara perceraian ke pengadilan tidak berfikir panjang dengan hasrat yang tinggi untuk berpisah istri melupakan hal penting bahwa di dalam isi surat gugatan bukan hanya tentang ingin cerai dan pembagian harta bersama atau yang lain, melainkan tentang nafkah anak.

Pencantuman tentang nafkah anak pada isi surat gugatan juga penting karena mengingat setelah bercerai suami juga masih wajib menafkahi anaknya sampai ia bisa mandiri, karena jikalau nafkah anak tidak di cantumkan dalam ini surat gugatan maka pada putusan sebentar hakim hanya membacakan dan memutuskan apa yang ada di dalam isi surat gugatan. Setelah adanya putusan maka berakhirnya segala hubungan antara suami dan istri kecuali anak, kebanyakan yang terjadi setelah pasca bercerai suami sudah tidak lagi mau menafkahi anaknya apalagi hak asuh jatuh kepada mantan istri. Suami hanya menafkahi kapan pun dia suka sehingga tidak ada kekuatan hukum mantan istri terhadap ketidak pemberian nafkah kepada anak karena pada saat bercerai suami tidak di kasih beban oleh pengadilan untuk wajib menafkahi anaknya sampai mandiri, semua itu di sebabkan karena di dalam surat gugatan tidak tertera tentang nafkah anak.

Berdasarkan mewawancara dengan seorang panitera, yaitu bapak Bambang Suroso, Beliau menyampaikan bahwa terjadinya kelalaian nafkah anak itu karena tidak diminta dalam isi gugatan, karena pengadilan agama tidak mencari-cari perkara melainkan memeriksa dan memutuskan perkara yang diminta. Kalau misalnya lalai 
karena tidak diminta dalam isi surat gugatan tentang nafkah anak maka itu bisa diminta tersendiri dalam sebuah gugatan baru. Tuntutan nafkah anak terdiri dari dua proses yaitu yang pertama nafkah yang dituntut oleh pihak tergugat, namanya gugatan rekonvensi (tuntutan balik), misalnya pihak penggugat tidak mencantumkan tentang nafkah anak maka oleh pihak tergugat menuntut agar supaya dalam proses gugatan dimasukan tuntutan tentang nafkah anak. Sedangkan yang kedua nafkah yang dituntut oleh pihak penggugat sudah ada maka hakim selanjutnya akan memeriksa proses perkara tersebut. Kalau misalnya lalai tidak meminta nafkah anak dalam isi surat gugatan, itu bisa diminta tersendiri dalam gugatan baru atas permintaan pihak penggugat. Kalau misalnya yang Jadi nafkah anak berlaku sejak terjadinya perceraian, nafkah anak dibayarkan setelah putusnya perkawinan, dihitung sejak saat itu sampai ke depan tentu ada perkiraan berapa perbulan kepada anak atau isi persentase. Karena pembayaran kadang-kadang ada yang ditetapkan oleh pengadilan berdasarkan penghasilan suami, misalnya anak masih berumur lima tahun kira-kira persentase nafkah sesuai penghasilan contohnya 1 juta setiap bulan kepada anak akan tetapi perkembangan anak makin besar makin membutuhkan biaya. Kalau di hitung berdasarkan presentasenya ketika pada saat anak itu besar pembayarannya juga pun lebih tinggi, tapi kalau berdasarkan keadaannya saja maka si anak rugi karena mau dia masih kecil atau sudah dewasa nafkah yang di berikan tetap sama (Wawancara dengan Narasumber, 2019).

\section{b. Ekonomi Suami Tidak Mencukupi}

Kelalaian nafkah anak bukan hanya terjadi karena tidak ada beban yang di kasih oleh pengadilan kepada mantan suami melaikan juga bisa terjadi di karenakan mantan suami mempunyai masalah dalam keuangan sehari-hari, mantan suami setelah pasca perceraian sudah mulai kehilangan kebugaran jasmaninya sehingga hanya bekerja pas-pasan saja.

Sehingga untuk menafkahi anaknya tidak sempurna dalam artian pemberian nafkah kepada anak itu hanya jikalau mantan suami mempunyai uang, maka demikian itu mantan suami menyampaikan bahwa dia tidak mampu menafkahi anaknya dikarenakan tidak memiliki ekonomi yang cukup, perkerjaanya pun tidak bisa mencukupi maka ia meminta bantuan mantan istri untuk sama-sama menafkahi anaknya walupun mereka berdua sudah bercerai. Hal tersebutlah sehingga pemenuhan nafkah anak bisa saja terlalaikan. Ini bisa jadi salah satu penyebab terjadinya perceraian juga karena masalah ekonomi tersebut. Ekonomi keluarga sangatlah penting bagi kesejahteraan keluarga akan tetapi manajeman keuangan juga lebih penting sehingga keungan keluarga terkontrol. 
Berdasarkan wawancara dengan hakim Pengadilan Agama Tondano Bapak Husnul Ma'Arif, beliau menyampaikan bahwa penyebab terjadinya kelalaian nafkah anak bukan hanya terjadi karena tidak dimasukannya nafkah anak dalam isi surat gugatan melainkan ada pula faktor lainya, seperti orang tua mempunyai ekonomi yang lemah dalam hal ini bapak sebagai orang tua genetis anak. Bapak tidak bisa memberi nafkah kepada anak sesuai kebutuhan anak dikarenakan pekerjaan yang dilakukan oleh bapak hanya sebatas kebutuhan sehari-hari, maka dari itu untuk membiayai anak mempunyai retan waktu tertentu. Pemberian nafkah kepada anak bisa saja dalam sebulan hanya satu kali diberi bahkan sebulan tersebut tidak di beri sama sekali, sehingga pemenuhan nafkah anak terlalaikan (Wawancara dengan Narasumber, 2020).

\section{c. Tidak Ada Rasa Tanggungjawab}

Anak merupakan amanah yang dititipkan oleh Allah kepada para orang tua. Sebagai amanah tentu anak tersebut harus dijaga dan diperhatikan kelangsungan hidupnya dengan sebaik-baiknya karena para orang tua akan dimintai pertanggungjawaban berkenaan dengan anugerah yang telah diberikan kepadanya.

Adapun tinjauan umun tentang anak yaitu, Berdasarkan Pasal 1 butir (1) UU No. 23 Tahun 2002 tentang Perlindungan Anak seseorang dapat dikatakan sebagai seorang anak jika "Seseorang yang belum berusia 18 tahun termasuk anak yang masih dalam kandungan". Anak mempunyai hak untuk mendapat perlindungan, yakni segala kegiatan untuk menjamin dan melindungi anak dan hak-haknya agar dapat hidup, tumbuh, berkembang, dan berpartisipasi secara optimal sesuai dengan harkat dan martabat kemanusiaan, serta mendapat perlindungan dari kekerasan dan diskriminasi (Undang-Undang Republik Indonesia Nomor 35 Tahun 2014 Tentang Perubahan Atas Undang-Undang Nomor 23 Tahun 2002 Tentang Perlindungan Anak).

Berdasarkan wawancara dengan hakim Pengadilan Agama Tondano Bapak Husnul Ma'Arif, beliau menyampaikan bahwa: Kewajiban orang tua dalam merawat dan membesarkan anak-anaknya sangatlah penting. Sehingga apapun yang terjadi anak pantas mendapatkan apa yang di dapat mulai dari rasa aman, kebutuhan dalam proses perkembangan dan lainya. Kelalaian nafkah anak pasca perceraian bukan hanya karena tidak ada tuntutan nafkah anak dalam isi surat gugatan atau orang tua yang tidak mampu, kelalaian juga bisa terjadi akibat orang tua dalam hal ini mantan suami melupakan tangguang jawab menafkahi pertumbuhan dan perkembangan anaknya. Akibat di atas sehinga nafkah anak terlalaikan tanggung jawab ayah sangatlah penting. Sesibuk apapun pekerjaan jangan pernah melupakan tanggung jawab yang di pikul karena akibat dari ketidak puasan dan kenyaman seorang anak 
anak maka anak tersebut bisa saja berubah tingkat psikologinya sehingga prilakuprilaku yang tidak baik mulai muncul dalam kepribadian anak tersebut (Wawancara dengan Narasumber, 2020).

Bukan hanya itu juga bisa jadi ayah dalam hal ini punya kewajiban memberi nafkah tidak mempunyai pemahaman yang mendalam tentang nafkah sehingga dia tidak mengetahui bahwa walaupun dirinya sudah bercerai dengan istrinya dia tetap punya kewajiban untuk menafkahi anaknya, oleh karena itu karena kurangnya pemahaman agama dan fiqh setelah bercerai dia sudah tidak ada lagi hubungan dengan istri maupun anakanaknya sehingga terjadilah kelalaian nafkah anak.

\section{Implementasi Nafkah Anak yang Tidak Dituntut dalam Surat Gugatan Pasca Perceraian}

Seperti yang dijelaskan di atas bahwa sebelum mengadakan tuntutan kembali berkaitan nafkah anak yang sebelumnya tidak di isi dalam surat gugatan istri yang menuntut menemui mantan suami atau pada pasca hakim meutuskan bahwa suami istri telah resmi berpisah dan disampaikan bahwa hak asuh anak jatuh pada istri maka disitulah istri mengajukan kesepakatan dengan mantan suami bahwa istri siap menjaga dan melindungi serta merawat anak akan tetapi suami juga harus menafkahi anak tersebut sampai anak itu bisa mandiri.

Meskipun yang berhak memelihara anak adalah ibu, namun dalam hal biaya pemeliharaan anak, ayah pun tetap berkewajiban untuk membiayainya. Karena telah berlaku dan ditetapkan dalam KHI pasal 156 huruf (d) dan (f) yaitu: akibat dari putusnya perkawinan karena perceraian ialah (d) semua biaya hadhanah dan nafkah anak menjadi tanggung jawab ayah sesuai dengan kemampuannya, sekurang kurangnya sampai anak tersebut dewasa dan dapat mengurus diri sendiri, (f) pengadilan dapat pula dengan mengingat kemampuan ayahnya menetapkan jumlah biaya pemeliharaan dan pendidikan anak yang tidak turut padanya (Direktorat Pembinaan Peradilan Agama Islam, 2001)

Seperti yang sudah di jelaskan pada Kompilasi Hukum Islam di atas bahwa ayah punya kewajiban penting untuk menafkahi anak. Selain itu untuk menambah data yang lebih kredibel, penulis kemudian mendapatkan penjelasan dari seorang panitera bahwa setelah adanya kesepakatan antar mantan suami istri tentang tanggungjawab mantan suami membiayai anaknya maka suami harus komitmen dengan kesepakatan tersebut. Akan tetapi apabila setelah adanya kesepakatan tersebut dan selama $1-3$ tahun berturut-turut mantan suami tidak melaksanakan kewajibanya memberi nafkah terhadap anaknya maka mantan istri boleh mengajukan tuntutan ke pengadilan terhadap kelalaian dari kesepakatan tersebut. 
Pihak akan senantiasa menerima dan memproses perkara tersebut dan mantan suami akan di kenakan ganti rugi kepada mantan istri akibat kelalaian tersebut. Hakim akan memutuskan berapa yang harus di bayar mantan suami kepada mantan istri sebagai ganti rugi. Hakim akan memberikan presentase jikalau nafkah anak yang dilalaikan itu terhitung dari putusnya perkawinan, apabila pada saat adanya putusan perceraian anak tersebut masih kecil dan kelalain yang terjadi dengan retan waktu yang lama maka pembayaran kepada anak makin tinggi sesuai kebutuhan anak tersebut. Selain itu juga hakim juga punya metode ganti rugi yang lain yaitu menargetkan berapa yang akan mantan suami bayar kepada mantan istri sebagai ganti rugi atas kelalaian yang terjadi yakni hakim sudah punya nominal tersendiri untuk menyetarakan pembiayaan tersebut, misalnya 5 juta setiap bulan yang akan di berikan kepada anak mulai dari anak tersebut masih kecil sampai usia yang sudah bisa mandiri, akan tetapi metode ini memungkinkan anak tersebut akan rugi, karna berbeda biaya masih kecil dan biaya ketika sudah besar apalagi anak tersebut anak perempuan.

Beda halnya dengan implementasi nafkah anak apabila ekonomi mantan suami tidak mencukupi maka, dalam hal ini istri juga harus paham mau diajak bicara serta membuang jauh-jauh keegoisan di dalam diri walaupun sudah pernah disakiti atau dikhianati. Sehingga komunikasi antar mantan suami dan istri juga bisa terjalin demi pertumbuhan dan perkembangan anak mereka. Karena jikalau juga bertahan dengan keegoisan masing-masing maka kelalaian nafkah anak bisa terjadi. Mantan istri harus siap menerima segala keluhan dan permintaan mantan suami untuk samasama bahu membahu memberikan kenyamanan dan keamanan bagi anaknya sendiri hingga sampai dia dewasa dan bisa mandiri. Hanya dengan jalan beginilah anak bisa menerima nafkahnya dari orangtuanya walaupun sudah bercerai.

\section{KESIMPULAN}

Terjadinya kelalaian nafkah anak pasca perceraian disebabkan oleh tiga faktor yaitu, pertama, tidak ada tuntutan dalam isi surat gugatan dalam artian istri ketika mengajukan gugatan ke pengadilan tidak memikirkan untuk mencantumkan tentang nafkah anak melaikan hanya gugatan cerai, harta bersama, hak asuh, dan lain sebagainya. Nafkah anak sangatlah penting karena apabila tidak tertera dalam isi surat gugatan maka tidak ada upaya hukum untuk menggugat mantan suami setelah adanya putusan pengadilan. Kedua, ekonomi suami sudah tidak mencukupi karena mantan suami memiliki masalah keuangan, kebugaran jasmani mulai berkurang dan bekerja hanya pas-pasan saja. Sehingga untuk menafkahi anak tidak sanggup lagi, itu pun saat suami mempunyai uang. Maka demikian itu mantan suami meminta bantuan kepada mantan istri untuk membantu menafkahi anaknya. Ketiga, tidak ada rasa 
tanggung jawab mantan suami kepada anaknya, terlebih jika hak asuh anak jatuh pada ibunya sehingga bapak dalam hal ini sebagai mantan suami berfikir masa bodoh, karena berharap ibunya yang akan menafkahi karena dia yang merawat dan memelihara petumbuhan serta perkembangan anak.

Untuk mendapatkan nafkah anak, walaupun tidak tertera dalam isi surat gugatan maka mantan istri harus bertemu dengan mantan suami guna untuk membicarakan tentang nafkah anak sehingga suami mempunyai rasa tanggung jawab yang besar menafkahi anaknya, akan tetapi mantan istri harus membuat perjanjian secara tertulis atau melalui notaris sehingga adanya kesepakatan bahwa mantan suami siap menafkahi anaknya walupun tidak ada dalam putusan pengadilan. Kemudian jika mantan suami melalaikan perjanjian yang telah disepakati kurun waktu 1-3 tahun maka mantan istri boleh mengajukan tuntutan baru ke pengadilan atas kelalaian nafkah anak tersebut, sehingga pengadilan akan memproses dan mantan suami akan dipanggil oleh pihak pengadilan untuk dimintai pertanggungjawaban atas kelalaian tersebut. Mantan suami akan dijatuhi hukuman denda sesuai pertimbangan hakim pengadilan agama.

\section{REFERENSI}

Ahmad Fahrur Rozi (2019). Analisis Fikih Empat Mazhab Terhadap Putusan Pengadilan Agama Kabupaten Malang Nomor 6884/Pdt.G/2015/Pa.Kab.Mlg tentang Nafkah Madiyah Anak Pasca Cerai Talak, UIN Sunan Ampel, Surabaya.

Achmad Rois Rijal (2017). Analisis Yuridis Terhadap Pandangan Hakim Pengadilan Agama Gresik tentang Nafkah Madiyah Anak Bagi Ibu Yang Sudah Menikah Lagi UIN Sunan Ampel, Surabaya.

Amiruddin, et.al. (2004) Pengantar Metode Penelitian Hukum. PT. Rajagrafindo Persada Jakarta. Cetakan kedua Desember.

Al Bukhari, Shahih Al-Bukhari, Juz 6 (Beirut: Dar Al Fikr).

Bagong Suyanto Dkk, (2000). Tindak Kekerasan terhadap Anak Masalah dan Upaya

Pemantauannya (Surabaya: Lutfhansa Mediatama.

Direktorat Pembinaan Peradilan Agama Islam, Kompilasi Hukum Islam.

Direktorat Pembinaan Peradilan Agama Islam (2001). Kompilasi Hukum Islam Jakarta: Ditjen Pembinaan Kelembagaan Islam Departemen Agama.

Jamiliya Susantin (2014). Implementasi Pemenuhan Nafkah Anak Pasca Putusnya

Perkawinan Karena Perceraian Di Pengadilan Agama Sumenep-Madura, Malang.

Kementrian Agama RI (2012). Al-Qur'an dan Terjemahannya PT. Sinergi Pustaka Indonesia. 
Nunung Rodliyah, =Akibat Hukum Perceraian Berdasarkan Undang-Undang Nomor 1 Tahun 1974 tentang Perkawinan', Keadilan Progresif, No.5.Vol. (2014),

Presiden RI, 'Undang-Undang Republik Indonesia Nomor 35 Tahun 2014 Tentang Perubahan Atas Undang-Undang Nomor 23 Tahun 2002 Tentang Perlindungan Anak', http:// www.Bphn.Go.Id (Jakarta, 2014),

Tim Redaksi BIP (2017). 3 Kitab Undang-Undang KUHPer, KUHP, KUHAP Beserta Penjelasannya, ed. by Saptono Rahardjo Jakarta: Bhuana Ilmu Populer. Wasman dan Wardah Nuroniyah (2011). Hukum Perkawinan Islam di Indonesia Yogyakarta: Teras. 